PRINT ISSN 1119-8362

Electronic ISSN 1119-8362
Full-text Available Online at

https://www.ajol.info/index.php/jasem

http://ww.bioline.org.br/ja
J. Appl. Sci. Environ. Manage.

Vol. 25 (12) 2047-2052 December 2021

\title{
Changes in Oxidative Stress Parameters in Wistar Rats Administered Soft Drink and Menthol Candy
}

\section{${ }^{* 1,2}$ ISOJE, EF; ${ }^{2}$ OKORO, IO}

\author{
${ }^{* 1,2}$ Department of Biochemistry, Faculty of Science, Delta State University, Abraka, Delta State, \\ Nigeria \\ ${ }^{2}$ Department of Science Laboratory Technology, School of Science and Technology, Delta State Polytechnic, Ozoro, Delta State, Nigeria \\ *Corresponding Author Email: mefegor@gmail.com, Other Author Email: Israelik@yahoo.com
}

\begin{abstract}
The present study aimed to evaluate changes of stress oxidative enzymes and electrolytes of wistar rats administered soft drink and menthol candy. Seventy Wistar rats of weight between $125 \mathrm{~g}$ and $175 \mathrm{~g}$ were utilized for the study. The rats were allowed to acclimatize for seven days. The rats were divided into 10 groups of seven rats as follows: Group 1: normal control, Group 2, 3 and 4 were given $8 \mathrm{ml}, 5$ and $2.5 \mathrm{ml} / \mathrm{kg}$ body weight lacasara. Group 5, 6 and 7 were given $0.3 \mathrm{~g}, 0.22 \mathrm{~g}$ and $0.11 \mathrm{~g} / \mathrm{kg}$ body weight tom-tom candy. Group 8,9 and 10 were administered $0.34 \mathrm{~g}$ in $8 \mathrm{ml}, 0.22 \mathrm{~g}$ in $5 \mathrm{ml}$ and $0.11 \mathrm{~g}$ in $2.5 \mathrm{ml} / \mathrm{kg}$ body weight of tom-tom mix with lacasara respectively. Treatment with tom-tom, lacasara and tom-tom mix with lacasara at various doses was carried out for 42 days. Electrolyte, creatinine and urea in the serum, superoxide dismutase (SOD), catalase (CAT) and malonyldialdehyde (MDA) in liver and kidney ware determined. The results showed significant increase in serum $\mathrm{Na}^{+}, \mathrm{K}^{+}, \mathrm{Cl}^{-}$and $\mathrm{LPO}$, decrease in SOD, and CAT, in the liver and kidney of groups $2,3,5,6,8,9$ and 10 compared to control. Furthermore, significant decrease was observed in LPO and increase SOD and CAT of group 7 in the liver and kidney compared to group 5 and 6 . There were no significant difference in creatinine and urea in the serum of group 7 compared to group 5 and 6 . In conclusion, chronic consumption of tom-tom, lacasara or tom-tom mix with lacasara induced oxidative stress. This effect was confirmed by kidney histological study, showing inflammation of proximal tubule and tubular cells.
\end{abstract}

\section{DOI: https://dx.doi.org/10.4314/jasem.v25i12.8}

Copyright: Copyright (C 2021 Isoje and Okoro. This is an open access article distributed under the Creative Commons Attribution License (CCL), which permits unrestricted use, distribution, and reproduction in any medium, provided the original work is properly cited.

Dates: Received: 22 August 2021; Revised: 17 September 2021; Accepted: 06 October 2021

Keywords: Candy, Electrolyte, Menthol, oxidative Stress, Soft drink and Tomtom.

Soft drinks and beverages consumption had been increased among young adult (Lebda et al., 2017). The ingredients of soft drink are water, sugar, phosphoric acid, fruit concentrate, preservatives, antioxidants, sweeteners, caffeine, carbon dioxide, and caramel as a colour additive (Düsman et al., 2013). Lacasara is a widely known soft drink that is consumed in arguably every part of the world including Nigeria (Blasco et al., 2020). Lacasera comprises of the following ingredients; apple juice ( $25 \%$ more), apple flavour, carbonated water, preservatives (sodium benzoate), malic acid, citric acid and sugar (Izah et al., 2017). Undoubtedly, soft drinks are a major source of added sugar worldwide, and their consumption has been linked to obesity, diabetes, and metabolic syndrome (Salau et al., 2013). Epidemiological and experimental evidence indicate that a greater consumption of sweet carbonated beverages is associated with overweight and obesity by virtue of the high sugar content and incomplete compensation for total energy in subsequent meals (Salau et al., 2013; Tucker et al., 2015; Yu et al., 2013). Tom-tom is one of the Nigerian candies with strong menthol flavor. Generally, menthol (monocyclic terpene) is considered as very safe alcohol which is widely used in food industry and medicine. Kumar et al. (2016) stated the toxicity of excessive menthol consumption. Mustapha (2018) reported that lacasera juice and tom-tom candy has been abused by drug addict. This mainly done by mixing the two products to form solution called gigabyte. The kidneys are organs found in all vertebrates. They get rid of waste products from the body and maintain balanced electrolyte levels. Oxidative stress is considered an important player in the pathophysiology of kidney disease. Kidney disease is characterized by an abrupt loss of kidney function. Some of the antioxidants that are of veritable importance in the body for counteracting of oxidative stress assaults are catalase, superoxide dismutase, GSH and GST (Nimse et al., 2011). Sucrose diet is also known for the lowering of the antioxidant system and overwhelming the body defence mechanism, consequently leading to oxidative stress (Potukuchi $e t$ al., 2018). Oxidative stress, electrolyte imbalance and 
dyslipidemia are therefore, some of the major pathological pathways of sucrose-induced disorders (Tukel et al., 2019). Therefore, the aim of this study was to investigate changes in stress oxidative enzymes and electrolytes of Wistar rats following chronic consumption of soft drink and menthol candy and the role of the tubular epithelial cells liberating proinflammatory mediators that could cooperate in regards to renal damage.

\section{MATERIALS AND METHODS}

Reagent and chemical: All reagent and chemicals that were used for this study were of analytical grade. The lacasera and tom-tom candy were purchased from Abraka main market, Delta State Nigeria.

Experimental Procedures: Seventy (70) male albino rats (Wistar strain) of weight between $125 \mathrm{~g}$ and $175 \mathrm{~g}$ were used for the study and were fed on standard laboratory diet (growers mash) and water ad libitum while the study lasted. .The rats were randomly grouped into 10 groups of seven rats as follows:

Group 1: normal control

Group 2: $8 \mathrm{ml} / \mathrm{kg}$ body weight lacasara

Group 3: $5 \mathrm{ml} / \mathrm{kg}$ body weight lacasara

Group 4: $2.5 \mathrm{ml} / \mathrm{kg}$ body weight lacasara

Group 5: $0.34 \mathrm{~g} / \mathrm{kg}$ body weight tom-tom

Group 6: $0.22 \mathrm{~g} / \mathrm{kg}$ body weight tom-tom

Group 7: $0.11 \mathrm{~g} / \mathrm{kg}$ body weight tom-tom

Group 8: $0.34 \mathrm{~g}$ in $8 \mathrm{ml} \mathrm{kg}$ body weight tom-tom mix with lacasara

Group 9: $0.22 \mathrm{~g}$ in $5 \mathrm{ml} \mathrm{kg}$ body weight tom-tom mix with lacasara

Group 10: $0.11 \mathrm{~g}$ in $2.5 \mathrm{ml} \mathrm{kg}$ body weight tom-tom mix with lacasara

Rats in group 2 to 10 were given lacasara and tom-tom orally (either combined or singly) for 42 days. At the end of the study (day 42), the rats were euthanized in an airtight glass chamber saturated with chloroform and after opening up the rats surgically, blood samples, liver and kidney was collected for the biochemical analyses.

\section{BIOCHEMICAL ANALYSES}

Determination of kidney function markers: Urea, creatinine, potassium chloride and sodium in the serum were determined colorimetrically according to standard procedures using commercially available diagnostic kits (Randox Laboratories Limited, England).

Determination of superoxide dismutase (SOD) activity: The activity of superoxide dismutase (SOD) in the liver and kidney was determined by following the auto-oxidation of epinephrine as described by Misra and Fridovich (1972). A portion $(0.2 \mathrm{~mL})$ of sample and $2.5 \mathrm{~mL}$ of $0.05 \mathrm{M}$ buffer (carbonate buffer $\mathrm{pH} 10.2$ ) was placed in test tube. Thereafter, $0.3 \mathrm{~mL}$ freshly prepared epinephrine as the substrate to the buffer supernatant and mixed. The reference cuvette was used as blank. The absorbance at $480 \mathrm{~nm}$ due to the adrenochrome formed was read every 30 seconds for 120 seconds.

Determination of Catalase Activity: The activity of catalase in the liver and kidney were determined by method of Claiborne et al. (1984). Two millilitres (2 $\mathrm{mL}$ ) of $\mathrm{H}_{2} \mathrm{O}_{2}$ was added to $1 \mathrm{~mL}$ of sample in the reaction cuvette. Sample was read at $360 \mathrm{~nm}$ for 70 seconds. The reference cuvette contained $2 \mathrm{~mL} \mathrm{H}_{2} \mathrm{O}_{2}$ and $1 \mathrm{~mL}$ of water. The disappearance of hydrogen peroxide was computed using the Molar extinction coefficient, $\varepsilon=39.4 \mathrm{M}^{-1} \mathrm{~cm}^{-1}$.

Estimation of Lipid Peroxidation: In the liver and kidney were done by the method of Buege and Aust (1978). One millilitre of the sample and $2 \mathrm{~mL}$ of TCATBA- $\mathrm{HCl}$ reagent $[0.37 \%$ TBA, $15 \%$ TCA and $0.24 \mathrm{~N}$ Hydrochloric acid $(\mathrm{HCl})]$ (1:1:1 ratio) was placed in test tube. The tube was then placed in boiling water $\left(100{ }^{\circ} \mathrm{C}\right)$ for $15 \mathrm{~min}$. The sample was cooled and centrifuged for $10 \mathrm{mins}$ at $5000 \mathrm{~g}$. The readings were taken at $532 \mathrm{~nm}$. LPO in units/g of wet tissue was calculated with a molar extinction co-efficient of 1.56 x $105 \mathrm{M}^{-1}$

\section{RESULTS AND DISCUSSION}

Soft drink mixed with lacasara has been incriminated in the induction of oxidative stress through elevation of the free radical production, lowering the antioxidant status and elevation of free radicals. Table 1 presented serum urea and creatinine level of rats administered tom-tom mix with lacasara. The observed significant increase $(\mathrm{p}<0.05)$ in serum urea level of rats administered $8 \mathrm{ml} / \mathrm{kg}$ body weight lacasara, $5 \mathrm{ml} / \mathrm{kg}$ body weight lacasara, $0.34 \mathrm{~g} / \mathrm{kg}$ body weight tom-tom, $0.34 \mathrm{~g}$ in $8 \mathrm{ml}, 22 \mathrm{~g}$ in $5 \mathrm{ml}$ and $0.11 \mathrm{~g}$ in $2.5 \mathrm{ml} \mathrm{kg}$ body weight tom-tom mix with lacasara (group 2, 3, 5, 8,9 and 10) compared to the control may likely be due to kidney damage caused by tom-tom mix with lacasara toxicity. The significant decrease $(\mathrm{p}<0.05)$ illustrated in urea and creatinine of rats administered $2.5 \mathrm{ml} / \mathrm{kg}$ body weight lacasara compared to $8 \mathrm{ml}$ and $5 \mathrm{ml} / \mathrm{kg}$ body weight lacasara (group 2 and 3 ) could be as a results of the low dose of lacasara which may cause no damage to the kidney. Studies have showed that elevated creatinine level signifies impaired kidney function (Hall et al., 2014). Hence this clearly showed that lacasara drink and tom-tom at low dose do not cause any kidney damage. Interestingly, no significant difference was indicated in urea and creatinine of rats given $0.34 \mathrm{~g}$ in $8 \mathrm{ml} \mathrm{kg}$ body weight tom-tom mix with 
lacasara (group 8) when compared to rats given 0.22 $\mathrm{g}$ in $5 \mathrm{ml}$ and $0.11 \mathrm{~g}$ in $2.5 \mathrm{ml} \mathrm{kg}$ body weight tomtom mix with lacasara (group 9 and 10). This may point to the fact that the effects of the mixture of lacasara and tom tom were not concentration dependent.

Table 1. Serum urea and creatinine level of rats administered tom-tom mix with lacasara

\begin{tabular}{lll}
\hline & Serum Urea $(\mathbf{m g} / \mathbf{d L})$ & Serum Creatinine $(\mathbf{m g} / \mathbf{d L})$ \\
\hline Group 1 & $22.20 \pm 11.05^{\mathrm{a}}$ & $0.38 \pm 0.14^{\mathrm{a}}$ \\
Group 2 & $30.00 \pm 9.30^{\mathrm{b}, \mathrm{c}}$ & $0.60 \pm 0.1^{\mathrm{b}}$ \\
Group 3 & $29.20 \pm 9.90^{\mathrm{b}}$ & $0.58 \pm 0.14^{\mathrm{b}}$ \\
Group 4 & $23.00 \pm 8.51^{\mathrm{a}}$ & $0.36 \pm 0.08^{\mathrm{a}}$ \\
Group 5 & $28.60 \pm 9.73^{\mathrm{b}}$ & $0.42 \pm 0.14^{\mathrm{a}}$ \\
Group 6 & $26.00 \pm 8.03^{\mathrm{a}, \mathrm{b}}$ & $0.40 \pm 0.14^{\mathrm{a}}$ \\
Group 7 & $19.00 \pm 4.39^{\mathrm{a}}$ & $0.30 \pm 0.07^{\mathrm{a}}$ \\
Group 8 & $36.60 \pm 5.10^{\mathrm{c}}$ & $0.68 \pm 0.13^{\mathrm{b}}$ \\
Group 9 & $35.00 \pm 8.36^{\mathrm{c}}$ & $0.58 \pm 0.14^{\mathrm{b}}$ \\
Group 10 & $35.80 \pm 8.81^{\mathrm{c}}$ & $0.66 \pm 0.19^{\mathrm{b}}$ \\
\hline in mean \pm SD. Mean values $(n=5)$ in the same column with different letter differ at $p<0.05$.
\end{tabular}

In this study, the serum electrolytes $\left(\mathrm{Na}^{+}, \mathrm{K}^{+}\right.$and $\left.\mathrm{Cl}^{-}\right)$ of rats administered $8 \mathrm{ml} / \mathrm{kg}$ body weight lacasara, 5 $\mathrm{ml} / \mathrm{kg}$ body weight lacasara, $0.34 \mathrm{~g} / \mathrm{kg}$ body weight tom-tom, $0.34 \mathrm{~g}$ in $8 \mathrm{ml}, 22 \mathrm{~g}$ in $5 \mathrm{ml}$ and $0.11 \mathrm{~g}$ in $2.5 \mathrm{ml} \mathrm{kg}$ body weight tom-tom mix with lacasara (group 2, 3, 5, 8, 9 and 10) were significantly higher compared to the control (Table 2), this may likely be due to damage of kidney caused by tom-tom mix with lacasara at high dose of administration. According to Calvo and Uribarri (2013) elevated electrolyte level $\left(\mathrm{Na}^{+}, \mathrm{K}^{+}\right.$and $\left.\mathrm{Cl}^{-}\right)$may be main factor giving rise to kidney failure and osteoporosis. Elevated electrolyte in the serum of rats might lead to disturbed regulation of hormones giving rise to osteoporosis and cardiovascular diseases (Jiao et al., 2019). Lacasara intake at low dose of $2.5 \mathrm{ml} / \mathrm{kg}$ body weight and 0.11 $\mathrm{g} / \mathrm{kg}$ body weight tom-tom, the serum $\mathrm{Na}^{+}, \mathrm{K}^{+}$and $\mathrm{Cl}^{-}$ were not significantly different compared to control. In addition, significant decrease $(\mathrm{p}<0.05)$ was observed in $\mathrm{Na}^{+}, \mathrm{K}^{+}$and $\mathrm{Cl}^{-}$of rats given $2.5 \mathrm{ml} / \mathrm{kg}$ body weight lacasara (group 4) compared to 8 and 5 $\mathrm{ml} / \mathrm{kg}$ body weight lacasara. This may be due to the fact that low dose of lacasara may not compromise the serum electrolyte level. Moreover, the serum $\mathrm{Na}^{+}, \mathrm{K}^{+}$ and $\mathrm{Cl}^{-}$of rats given $0.34 \mathrm{~g}$ in $8 \mathrm{ml} \mathrm{kg}$ body weight tom-tom mix with lacasara indicated no significant difference when compared to rats given $0.22 \mathrm{~g}$ in $5 \mathrm{ml}$ and $0.11 \mathrm{~g}$ in $2.5 \mathrm{ml} \mathrm{kg}$ body weight tom-tom mix with lacasara. This may point to the fact that the dose were not in concentration dependent.

Table 2. Effects of tom-tom mix with lacasara consumption on serum $\mathrm{Na}^{+}, \mathrm{K}^{+}$and $\mathrm{Cl}^{-}$levels of rats.

\begin{tabular}{clll}
\hline & $\mathbf{N a}^{+}(\mathbf{m E q} / \mathbf{L})$ & $\mathbf{K}^{+}(\mathbf{m E q} / \mathbf{L})$ & $\mathbf{C l}{ }^{-}(\mathbf{m E q} / \mathbf{L})$ \\
\hline Group 1 & $148.60 \pm 4.39^{\mathrm{a}}$ & $6.82 \pm 1.76^{\mathrm{a}}$ & $111.20 \pm 6.14^{\mathrm{a}}$ \\
Group 2 & $170.60 \pm 2.96^{\mathrm{b}}$ & $10.80 \pm 0.82^{\mathrm{b}}$ & $125.60 \pm 5.54^{\mathrm{b}}$ \\
Group 3 & $168.40 \pm 1.94^{\mathrm{b}}$ & $10.60 \pm 5.58^{\mathrm{b}}$ & $124.40 \pm 8.08^{\mathrm{b}}$ \\
Group 4 & $150.60 \pm 23.17^{\mathrm{a}}$ & $6.58 \pm 1.74^{\mathrm{a}}$ & $113.40 \pm 14.02^{\mathrm{a}}$ \\
Group 5 & $160.20 \pm 19.71^{\mathrm{c}}$ & $8.16 \pm 4.55^{\mathrm{a}}$ & $123.60 \pm 18.56^{\mathrm{b}}$ \\
Group 6 & $163.20 \pm 21.11^{\mathrm{c}}$ & $9.18 \pm 0.85^{\mathrm{a}, \mathrm{b}}$ & $120.80 \pm 26.15^{\mathrm{b}}$ \\
Group 7 & $143.40 \pm 29.95^{\mathrm{a}}$ & $7.20 \pm 2.71^{\mathrm{a}}$ & $110.00 \pm 25.79^{\mathrm{a}}$ \\
Group 8 & $188.40 \pm 1.67^{\mathrm{d}}$ & $12.86 \pm 2.28^{\mathrm{b}, \mathrm{c}}$ & $136.20 \pm 1.92^{\mathrm{c}}$ \\
Group 9 & $187.60 \pm 43.78^{\mathrm{d}}$ & $12.66 \pm 5.43^{\mathrm{b}, \mathrm{c}}$ & $135.80 \pm 16.39^{\mathrm{c}}$ \\
Group 10 & $188.00 \pm 50.36^{\mathrm{d}}$ & $12.74 \pm 10.43^{\mathrm{b}, \mathrm{c}}$ & $136.00 \pm 45.30^{\mathrm{c}}$ \\
\hline Values are given in mean $\pm S D$. Mean values $(n=5)$ in the same column with different letter differ at $p<0.05$.
\end{tabular}

In this study, a significant decrease $(\mathrm{p}<0.05)$ in liver and kidney SOD, CAT activities and increase in MDA level of rats given lacasara at $8 \mathrm{ml}, 5 \mathrm{ml} / \mathrm{kg}$ body weight, tom-tom at $0.34 \mathrm{~g} / \mathrm{kg}$ body weight, $0.34 \mathrm{~g}$ in 8 $\mathrm{ml}, 22 \mathrm{~g}$ in $5 \mathrm{ml}$ and $0.11 \mathrm{~g}$ in $2.5 \mathrm{ml} / \mathrm{kg}$ body weight of tom-tom mix with lacasara in comparison to the control (Table 3 and 4), were observed. Chronic consumption of tom-tom, lacasara and tomtom mix with lacasara at high dose may induced oxidative stress which may lead to alteration of antioxidant enzymes and lipid peroxidation. This is in accordance to the work of Alkhedaide et al. (2016) who reported that chronic consumption of soft drink -induced oxidative stress, which may cause hepatic damage and nephrotoxicity, as indicated by the increase in MDA and the decrease in SOD and catalase levels. Soft drinks are the predominant source of sugar and are associated with obesity in children and adolescents. Soft drinks favor the incidence of insulin resistance and inflammation, and other diseases, including obesity, type- 2 diabetes, osteoporosis and low nutrient level Alkhedaide et al. (2016). Also, significant increase was recorded in SOD, CAT activities and decrease in MDA level in the liver and kidney of rats given $2.5 \mathrm{ml} / \mathrm{kg}$ body weight lacasara compared to higher dose of $8 \mathrm{ml}$ and $5 \mathrm{ml} / \mathrm{kg}$ body weight lacasara. 
Interestingly, low dose of tom-tom at $0.11 \mathrm{~g} / \mathrm{kg}$ body weight significantly increase $(\mathrm{p}<0.05)$ in SOD, CAT activities and decrease MDA level in the liver and kidney in comparison to higher dose of $0.22 \mathrm{~g}$ and 0.34 $\mathrm{g} / \mathrm{kg}$ body weight tom-tom. This finding of this study suggests that decrease in MDA of rats given low dose of lacasara over high dose would be prudent to recommend decrease in soft drink consumption. The fact that soft drinks offer energy with little accompanying nutrition, displace other nutrient sources, and are linked to alteration of biochemical parameters and several key health conditions such as diabetes is further impetus to recommend a reduction in soft drink consumption (Huang at al., 2018; Vartanian et al., 2007).

Table 3. Liver SOD, CAT activities and MDA level of rats administered tom-tom mix with lacasara

\begin{tabular}{|c|c|c|c|}
\hline & $\begin{array}{lr}\begin{array}{l}\text { Liver } \\
\text { (Units/g }\end{array} & \text { SOD } \\
\text { tissue) } & \text { wet } \\
\end{array}$ & $\begin{array}{l}\text { Liver } \\
\text { CAT(Units/g } \\
\text { wet tissue) }\end{array}$ & $\begin{array}{l}\text { Liver } \\
\text { MDA(Units/g } \\
\text { wet tissue) }\end{array}$ \\
\hline Group 1 & $15.35 \pm 2.95^{\mathrm{a}}$ & $25.27 \pm 3.83^{\mathrm{a}}$ & $0.18 \pm 0.02^{\mathrm{a}}$ \\
\hline Group 2 & $8.21 \pm 2.55^{\mathrm{b}}$ & $17.19 \pm 7.22^{b}$ & $1.19 \pm 0.25^{b}$ \\
\hline Group 3 & $11.27 \pm 1.74^{\mathrm{b}, \mathrm{c}}$ & $20.30 \pm 2.64^{\mathrm{a}, \mathrm{b}}$ & $1.01 \pm 0.38^{\mathrm{b}}$ \\
\hline Group 4 & $16.19 \pm 4.38^{\mathrm{a}}$ & $25.18 \pm 7.17^{\mathrm{a}}$ & $0.19 \pm 0.02^{\mathrm{a}}$ \\
\hline Group 5 & $10.31 \pm 3.63^{b, c}$ & $19.19 \pm 2.90^{\mathrm{a}, \mathrm{b}}$ & $0.83 \pm 0.19^{\mathrm{a}, \mathrm{b}}$ \\
\hline Group 6 & $11.50 \pm 1.58^{b, c}$ & $21.05 \pm 5.28^{\mathrm{a}, \mathrm{b}}$ & $0.29 \pm 0.22^{\mathrm{a}}$ \\
\hline Group 7 & $15.63 \pm 4.24^{\mathrm{a}}$ & $27.42 \pm 2.11^{\mathrm{a}}$ & $0.15 \pm 0.03^{\mathrm{a}}$ \\
\hline Group 8 & $7.33 \pm 2.47^{b}$ & $14.35 \pm 3.37^{\mathrm{c}}$ & $2.01 \pm 0.38^{\mathrm{b}}$ \\
\hline Group 9 & $7.27 \pm 4.27^{\mathrm{b}}$ & $15.26 \pm 7.97^{\mathrm{c}}$ & $2.01 \pm 0.63^{\mathrm{b}}$ \\
\hline Group 10 & $7.31 \pm 2.40^{\mathrm{b}}$ & $14.28 \pm 2.26^{c}$ & $1.98 \pm 0.12^{b}$ \\
\hline
\end{tabular}

Values are given in mean $\pm S D$. Mean values $(n=5)$ in the same column with different letter differ at $p<0.05$.

Table 4. Changes in kidney SOD, CAT and MDA level of rats given tom-tom mix with lacasara

\begin{tabular}{llll}
\hline & $\begin{array}{l}\text { Kidney SOD } \\
\text { (Units/g } \\
\text { tissue) }\end{array}$ & $\begin{array}{l}\text { Kidney } \\
\text { CAT(Units/g } \\
\text { wet tissue) }\end{array}$ & $\begin{array}{l}\text { Kidney MDA } \\
\text { (Units/g wet } \\
\text { tissue) }\end{array}$ \\
\hline Group 1 & $10.30 \pm 2.25^{\mathrm{a}}$ & $20.26 \pm 3.65^{\mathrm{a}}$ & $0.16 \pm 0.02^{\mathrm{a}}$ \\
Group 2 & $6.17 \pm 0.67^{\mathrm{b}}$ & $12.28 \pm 1.49^{\mathrm{b}}$ & $0.79 \pm 0.36^{\mathrm{b}}$ \\
Group 3 & $8.37 \pm 1.52^{\mathrm{b}}$ & $15.71 \pm 2.149^{\mathrm{b}, \mathrm{c}}$ & $0.61 \pm 0.22^{\mathrm{b}}$ \\
Group 4 & $10.32 \pm 1.35^{\mathrm{a}}$ & $19.15 \pm 1.61^{\mathrm{a}}$ & $0.11 \pm 0.04^{\mathrm{a}}$ \\
Group 5 & $8.29 \pm 3.71^{\mathrm{b}}$ & $14.11 \pm 2.84^{\mathrm{b}}$ & $0.43 \pm 0.14^{\mathrm{c}}$ \\
Group 6 & $9.50 \pm 3.59^{\mathrm{a}, \mathrm{b}}$ & $14.19 \pm 3.189^{\mathrm{b}}$ & $0.21 \pm 0.08^{\mathrm{a}}$ \\
Group 7 & $12.53 \pm 1.64^{\mathrm{a}, \mathrm{c}}$ & $23.18 \pm 3.57^{\mathrm{a}}$ & $0.15 \pm 0.02^{\mathrm{a}}$ \\
Group 8 & $5.01 \pm 1.84^{\mathrm{b}}$ & $9.50 \pm 3.28^{\mathrm{b}}$ & $0.94 \pm 0.19^{\mathrm{d}}$ \\
Group 9 & $5.27 \pm 0.16^{\mathrm{b}}$ & $10.35 \pm 2.45^{\mathrm{b}}$ & $1.00 \pm 0.39^{\mathrm{d}}$ \\
Group 10 & $5.29 \pm 0.69^{\mathrm{b}}$ & $10.10 \pm 3.48^{\mathrm{b}}$ & $1.01 \pm 0.22^{\mathrm{d}}$ \\
\hline
\end{tabular}

Values are given in mean $\pm S D$. Mean values $(n=5)$ in the same column with different letter differ at $p<0.05$.

The kidney histology of rats administered tom-tom mix with lacasara is presented in plates 1 to 10 . . The kidney histology of the normal rats (group 1), group 4 and 7, showed normal proximal tubular cells with glomerulus attached to bowman's capsule. Interestingly, $2.5 \mathrm{ml} / \mathrm{kg}$ body weight lacasara (group 4) and $0.11 \mathrm{~g} / \mathrm{kg}$ body weight tom-tom (group 7) had similar architecture (glomerulus was well attached to bowman's capsule) in comparison with the control (Plates 1 - 10). The rats in group 2, 3, 5, 8, 9 and 10 showed glomerulus detachment from bowman's capsule, inflammation of proximal tubule and inflammation of tubular cells. These effect may connect with the alteration observed in serum urea, creatinine and electrolyte in this study.

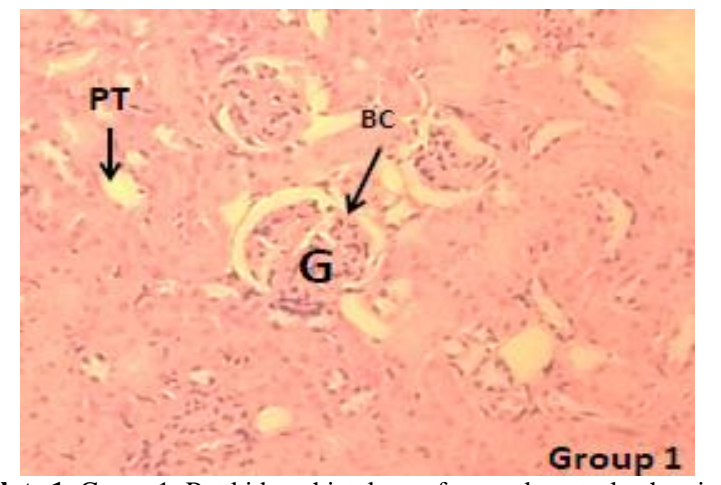

Plate 1: Group 1: Rat kidney histology of normal control: showing normal proximal tubular cells (PT) with glomerulus $(\mathrm{G})$ attached to bowman's capsule (BC) (H\&E stain x400). 


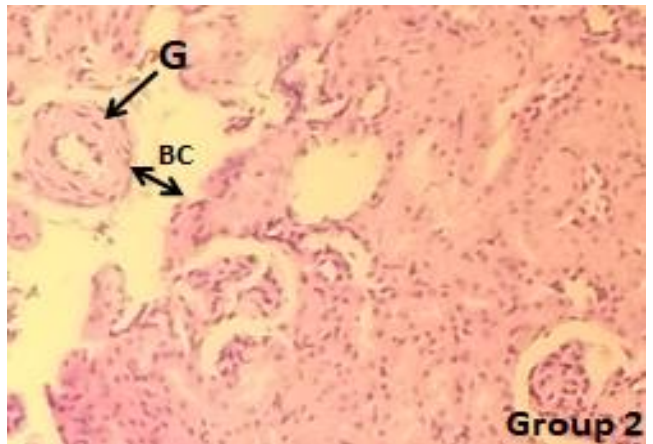

Plate 2. Group 2: Rat kidney histology given $8 \mathrm{ml} / \mathrm{kg}$ body weight lacasara, showing glomerulus $(\mathrm{G})$ detachment from bowman's capsule (BC) (H\&E stain x400).

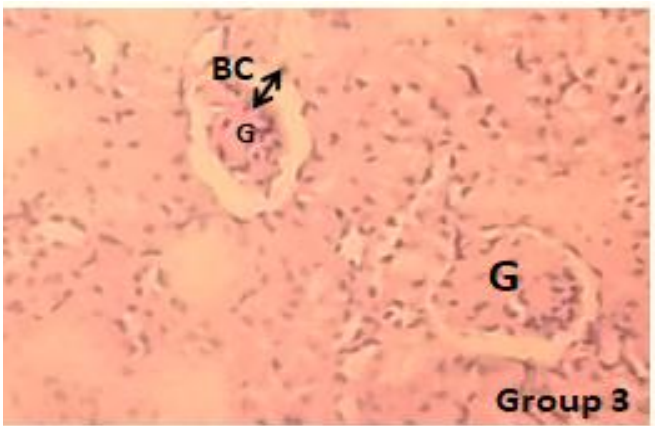

Plate 3. Group 3: $5 \mathrm{ml} / \mathrm{kg}$ body weight lacasara, showing mild detachment of glomerulus $(\mathrm{G})$ from bowman's capsule (BC) (H\&E stain $\mathrm{x} 400$ ).

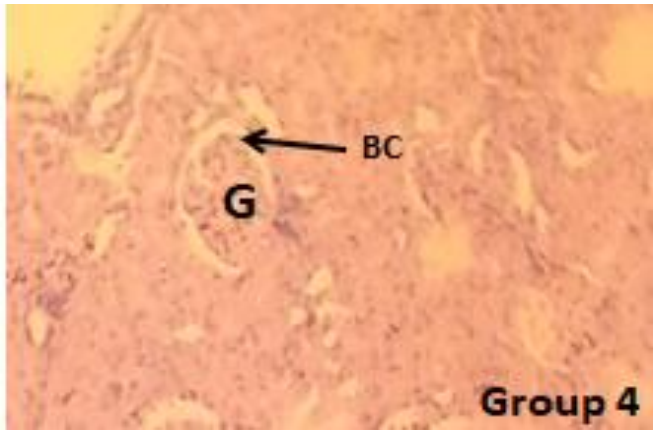

Plate 4. Group 4: $2.5 \mathrm{ml} / \mathrm{kg}$ body weight lacasara, showing glomerulus $(\mathrm{G})$ attached to bowman's capsule (BC) (H\&E stain $\mathrm{x} 400)$.

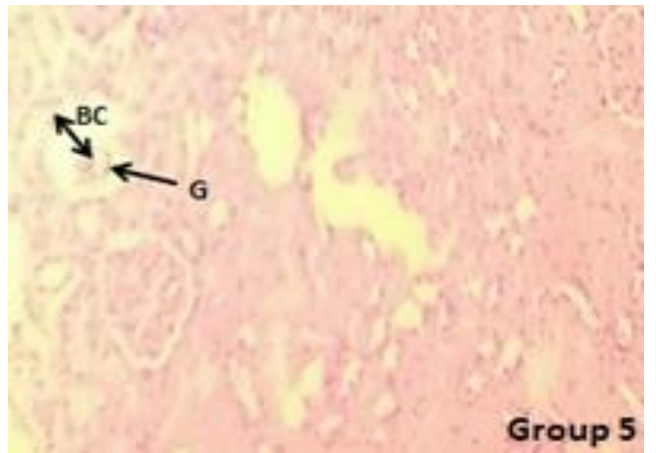

Plate 5. Group 5: $0.34 \mathrm{~g} / \mathrm{kg}$ body weight tom-tom, showing mild detachment of glomerulus $(\mathrm{G})$ from bowman's capsule (BC) (H\&E stain $\mathrm{x} 400)$.

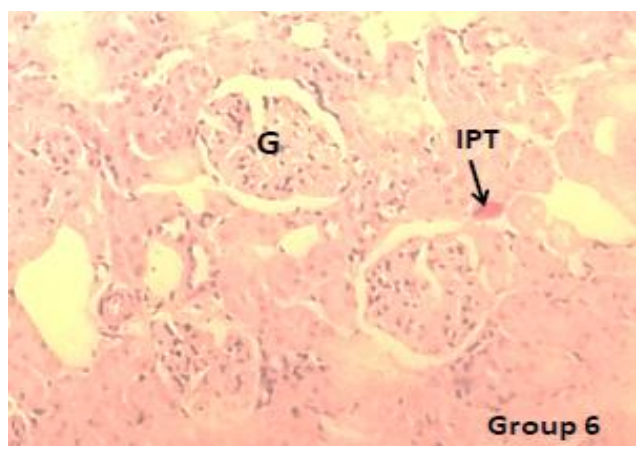

Plate 6. Group 6: $0.22 \mathrm{~g} / \mathrm{kg}$ body weight tom-tom, showing inflammation of proximal tubule (IPT) (H\&E stain $\mathrm{x} 400)$.

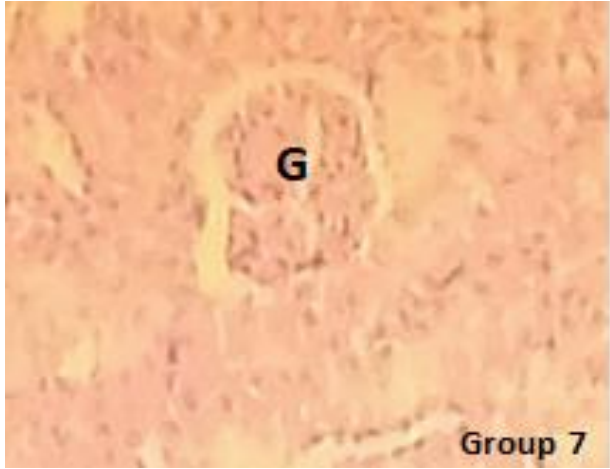

Plate 7. Group 7: $0.11 \mathrm{~g} / \mathrm{kg}$ body weight tom-tom, showing glomerulus $(\mathrm{G})$ attached to bowman's capsule $(\mathrm{BC})$

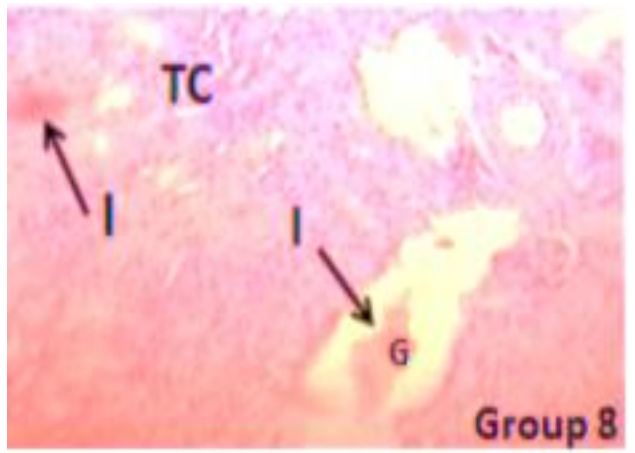

Plate 8. Group 8: $0.34 \mathrm{~g}$ in $8 \mathrm{ml} \mathrm{kg}$ body weight tom-tom mix with lacasara, showing inflammation of tubular cells (TC) and glomerulus $(\mathrm{G})(\mathrm{H} \& \mathrm{E}$ stain $\mathrm{x} 400)$.

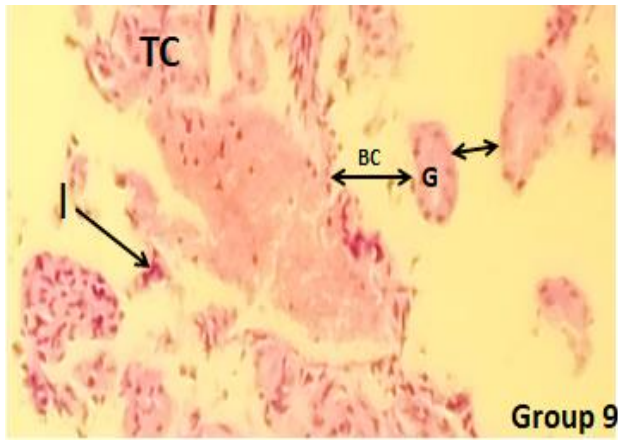

Plate 9. Group 9: $0.22 \mathrm{~g}$ in $5 \mathrm{ml} \mathrm{kg}$ body weight tom-tom mix with lacasara, showing inflammation (I) of tubular cells (TC) and detachment of glomerulus $(\mathrm{G})$ from bowman's capsule (BC) (H\&E stain $\mathrm{x} 400$ ). 


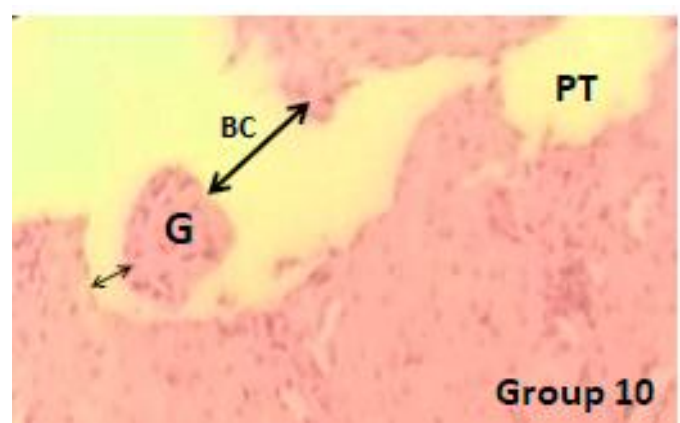

Plate 10. Group 10: $0.11 \mathrm{~g}$ in $2.5 \mathrm{ml} \mathrm{kg}$ body weight tom-tom mix with lacasara, showing proximal tubules (PT) and detachment of glomerulus (G) from bowman's capsule (BC) (H\&E stain x400).

Conclusion: This study warns about the consequences of chronic consumption of soft drink mixed with menthol candy in regards to alterations of oxidative enzymes, electrolytes and renal architecture. Additionally, the findings of this study also emphasize on the moderate intake of soft drink and menthol candy in regards to avoidance of renal damage.

\section{REFERENCES}

Alkhedaide, A; Soliman, MM; Salah-Eldin, AE; Ismail, TA; Alshehiri, ZS; Attia, HF (2016). Chronic effects of soft drink consumption on the health state of Wistar rats: A biochemical, genetic and histopathological study. Mol. Med. Rep., 13(6), 5109-5117.

Blasco, MM; Jiménez-Morales, M (2020). Soft Drinks and Sugar-Sweetened Beverages Advertising in Spain: Correlation between Nutritional Values and Advertising Discursive Strategies. Int. J. Environ. Res. Public Health 17(7): 2335-2346.

Buege, JA; Aust, SD (1978). Microsomal lipid peroxidation. Enzym. Meth. 52: 302-305.

Calvo, M S; Uribarri, J (2013). Public health impact of dietary phosphorus excess on bone and cardiovascular health in the general population. Am. J. Clin. Nutr. 98(1), 6-15.

Claiborne, A (1984). Catalase activity, in: R.A. Greenwald (Ed.), Handbook of Methods for Oxygen Radical Research, CRC Press Inc., Boca Raton, p. 283-284.

Hall, AC; Butterworth, J; Winsor, J; Kramer, J; NyeLengerman, K; Timmons, J (2018). Building an Evidence-Based, Holistic Approach to Advancing Integrated Employment .RPSD, 43(3), 207-218.

Huang, X; Zhang, J; Li, J; Zhao, S; Xiao, Y; Huang, Y; Shen, M (2018). Daily Intake of Soft Drinks and Moderate-to-Severe Acne Vulgaris in Chinese Adolescents. J. Pediatr. 204:256-262.

Izah, SC; Nyang, IR; Okowa, IF (2017). A review of heavy metal concentration and potential health implications of beverages consumed in Nigeria. Toxics 5, (1):1-15.
Jiao, D; Shuai, G; Yafei, C; Yong Z; Hailong, A (2019). Ion Channels and Bone Homeostasis Imbalance. Biomed. J. Sci. Tech Res. 16(3): 12088- 12093.

Kumar, A; Baitha, U; Aggarwal, P; Jamshed, N (2016). A fatal case of menthol poisoning. Int. J. Appl. Basic Med. Res. 6(2): 137-139.

Lebda, MA; Sadek, KM.; El-Sayed, YS (2017). Aspartame and Soft Drink-Mediated Neurotoxicity in Rats: Implication of Oxidative Stress, Apoptotic Signaling Pathways, Electrolytes and Hormonal Levels. Metab. Brain Dis. 32(5), 1639-1647.

Misra, HP; Fridovich, I (1972). The role of superoxide anion in the autooxidation of epinephrine and a sample assay for superoxide dismutase. Jpn Biochem. Soc. 247: 3170-3175.

Nimse, SB; Pal, D (2015). Free radicals, natural antioxidants and their reaction mechanisms. RSC Adv., 5: 2798628006.

Potukuchi, A; Addepally, U; Sindhu, K; Manchala, R (2018). Increased total DNA damage and oxidative stress in brain are associated with decreased longevity in high sucrose diet fed WNIN/Gr-Ob obese rats. Nutr. Neurosci., 21: 648-656.

Salau, BA; Ketiku,AO; Adebayo,OL; Olooto,WE; E.O. Ajani EO; Osilesi, O ( 20130). Modulation of cardiovascular risk factors (haematological and haemorrheological parameters) caused by sucrose diet. Am. J. Biochem. Mol. Biol. 3: 119-126.

Tucker PS; Scanlan AT; Dalbo VJ (2015), High Intensity Interval Training Favourably Affects Angiotensinogen mRNA Expression and Markers of Cardiorenal Health in a Rat Model of Early-Stage Chronic Kidney Disease. Biomed Res Int. 156584. Pmid: 26090382

Tukel, HC; Delilbasi, E (2019). Effects of metabolic syndrome on jawbones and bone metabolic markers in sucrose-fed rats. Odontol. 107: 457-464.

Vartanian, LR; Schwartz, M B; Brownell, KD (2007). Effects of Soft Drink Consumption on Nutrition and Health: A Systematic Review and Meta-Analysis. Am. J. Public Health 97(4), 667-675.

Yu F; Xu B; Song C; Ji L; Zhang X (2013). Treadmill exercise slows cognitive deficits in aging rats by antioxidation and inhibition of amyloid production. Neuroreport. 24: 342-347. 